\title{
Immunotherapeutic approaches for hepatocellular carcinoma
}

\author{
Vito Longo ${ }^{1, *}$, Antonio Gnoni ${ }^{2, *}$, Andrea Casadei Gardini ${ }^{3}$, Salvatore Pisconti ${ }^{1}$, \\ Antonella Licchetta ${ }^{2}$, Mario Scartozzi ${ }^{4}$, Riccardo Memeo ${ }^{5}$, Vincenzo Ostilio \\ Palmieri', Giuseppe Aprile7, Daniele Santini ${ }^{8}$, Patrizia Nardulli ${ }^{9}$, Nicola Silvestris ${ }^{10}$ \\ and Oronzo Brunetti ${ }^{10}$

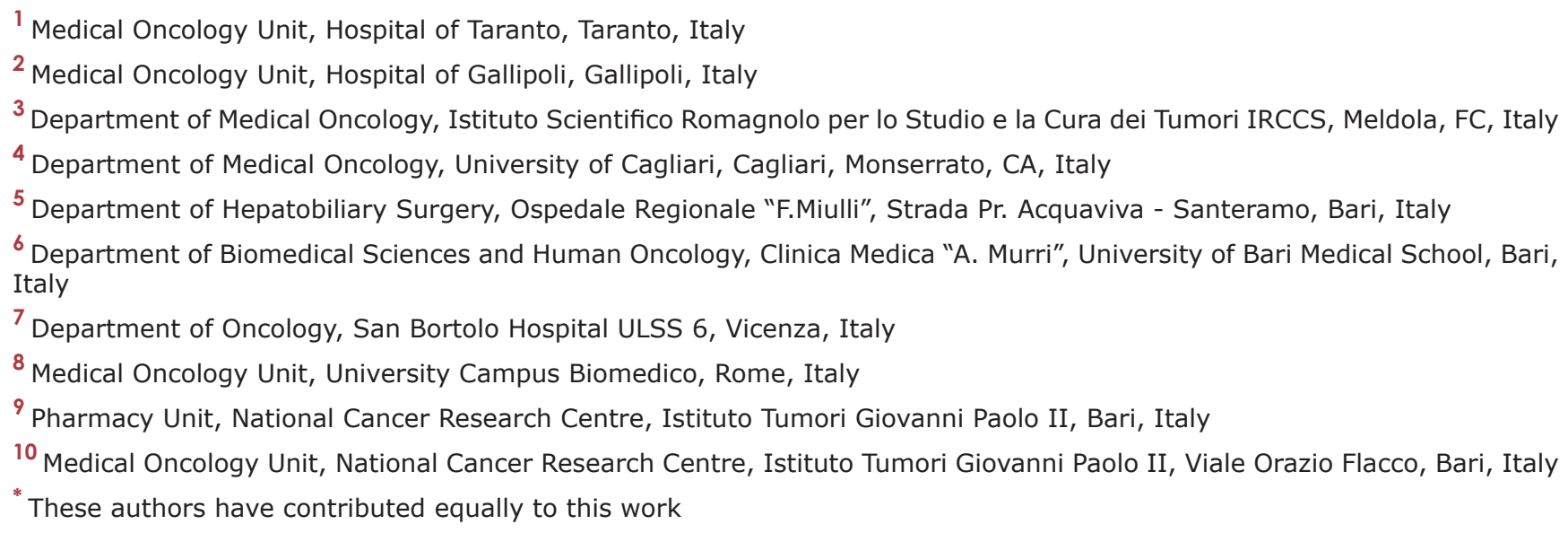 \\ Correspondence to: Oronzo Brunetti, email: dr.oronzo.brunetti@tiscali.it \\ Keywords: adoptive immunotherapy; dendritic cell vaccination; hepatocellular carcinoma; immunotherapy; immune checkpoint \\ Received: December 08, $2016 \quad$ Accepted: February 01,2017 Published: February 16, 2017
}

Copyright: Longo et al. This is an open-access article distributed under the terms of the Creative Commons Attribution License (CC-BY), which permits unrestricted use, distribution, and reproduction in any medium, provided the original author and source are credited.

\section{ABSTRACT}

Hepatocellular carcinoma (HCC) is a cancer with a high mortality rate due to the fact that the diagnosis usually occurs at anadvanced stage. Even in case of curative surgical treatment, recurrence is common. Sorafenib and regorafenib are the only therapeutic agents that have been demonstrated to be effective in advanced HCC, thus novel curative approaches are urgently needed. Recent studies focus on the role of immune system in HCC. In fact, the unique immune response in the liver favors tolerance, which can represent a real challenge for conventional immunotherapy in these patients. Spontaneous immune responses against tumor antigens have been detected, and new immune therapies are under investigation: dendritic cell vaccination, immune-modulator strategy, and immune checkpoint inhibition. In recent years different clinical trials examining the use of immunotherapy to treat HCC have been conducted with initial promising results. This review article will summarize the literature data concerning the potential immunotherapeutic approaches in HCC patients.

\section{INTRODUCTION}

Hepatocellular carcinoma (HCC) is one of most frequently diagnosed malignances and the third cause of cancer-related deaths worldwide, with about 600,000 death/years [1]. About $80 \%-90 \%$ of HCC developed into cirrhotic liver disease due to chronic viral hepatitis B or $\mathrm{C}$ [2]. Although surgery plays a fundamental role in the early stages, most of HCC patients diagnosed at an advanced stage of the disease or with hepatic impairment are treated with loco-regional or systemic therapies. Recurrence is observed in most of them within 5 years [3]. Only sorafenib and regorafenib, two oral multi-kinase inhibitors, have shown efficacy in advanced stages of this disease, providing a short increase of median overall survival (mOS) [4-6]. 
Gastrointestinal cancer immunotherapy has had significant progress in the last few years [7]. In particular, recent studies focus on the role of immune system in HCC. The unique immune response in the liver favors tolerance, which could represent a genuine challenge for conventional therapies in HCC patients [8].

\section{FROM LIVER IMMUNE SYSTEM TO HCC IMMUNE DISORDERS AND IMMUNOTHERAPEUTIC STRATEGY}

The liver is an organ with a specific blood supply. Approximately $25 \%$ and $75 \%$ of the blood enters the liver through the hepatic artery and the portal vein, respectively. The latter drains into smaller diameter structures called sinusoids. Vascular resistance is very low in these structures, and the portal venous blood, which is loaded with nutrients and many microbial antigens from the intestine, flows extremely slowly into the sinusoids. In this phase, antigens are in contact with a great number of nonparenchymal cells including liver sinusoidal endothelial cells (LSECs), hepatic stellate cells (h-SCs), Kupffer cells, dendritic cells (DCs), and lymphocytes. All these actors are potential protagonists in immune response.

Under physiological conditions, different digestion metabolites and bacteria coming from the bowel to the liver passing through the portal system represent an antigenic hyperstimulation. To overcome autoimmune mechanisms, the liver develops a series of mechanisms aiming at self-tolerance: i) decrease of costimulatory immune receptors such as B7-1, B7-2; ii) up-regulation of programmed cell death protein 1 (PD-1) receptor and cytotoxic T-limphocite antigen-4 (CTLA4) immunocheckpoint inibitors on hepatic antigen presenting cells (h-APC) such as h-SCs, LSECs, and Kupffer cells $[9,10]$; iii) secretion of cytokines with interleukin (IL)-10 and transforming growth factor $\beta$ (TGF- $\beta$ ) most studied $[11,12]$. Similarly, hepatitis B virus or hepatitis $C$ virus (HCV) infection, autoimmune hepatitis, alcohol abuse, non-alcoholic steatohepatitis lead to frequent chronic inflammatory liver insult resulting in a deregulation of $\mathrm{T}$ cell activities [13] with an increase of the expression of immune checkpoint inhibitors on h-APCs [14]. Moreover, tumor growth is favored by these mechanisms, which result amplified in HCC patients [15]. Cancer associated fibroblasts, essential components of the HCC microenviroment, inhibit natural killer (NK) cell function by releasing the immunosuppressive molecules prostaglandin E2 and indoleamine 2,3 dioxygenase (IDO) [16]. Moreover, several data support a possible correlation between the phenotype of infiltrating lymphocytes and the risk of relapse after transplantation or loco-regional treatments [17]. With regard to this, the expression of T-helper1 cytokines such as IL- $1 \alpha$, IL-1 $\beta$, IL-2, and interferon (IFN)- $\gamma$ in tumor tissue is associated with good prognosis, whereas T-helper2 cytokines such as IL-
4, IL-5, and IL-10 are upregulated in aggressive disease [8]. As well as in other solid tumors, forkhead box P3 (FOXP3) + T-regs, a subset of CD4+ T cells specialized in the suppression of the host immune system against self antigens, promotes tumor development inducing a state of severe immune-suppression in HCC [18]. The suppressive function of FOXP3 + T-regs may be related to different mechanisms such as target cells killing by T-regs, modulation of target cell signaling via cell-cell contact, and secretion of immunosuppressive cytokines such as IL-10, IL-35, and TGF- $\beta$. The epigenetic regulation is patho-physiologically relevant for T-regs function and development . Furthermore, epigenetic mechanisms responsible for regulating the foxp3 gene expression have a key role in T-regs suppressive activity [19,20]. Moreover, an increased number of $\mathrm{CD}^{+} \mathrm{CD}^{+} 5^{+} \mathrm{FOXP} 3^{+}$Treg may reduce the activity of $\mathrm{CD}^{+} \mathrm{T}$ cells, promoting disease progression, with high mortality and reduced survival of these patients [21]. Subsequently, programmed cell death protein-ligand (PD-L) expression and FOXP3+ T-reg cell expression have been analyzed on tissue of 240 resected HCC patients, with a cross validation in an independent cohort of 125 HCC samples. Patients with a higher PD-L1 tumor expression had a significantly poorer prognosis than patients with lower expression. The multivariate analysis demonstrated that PD-L1 expression was an independent predictor of recurrence after surgery. The prognostic value of PD-L1 expression was validated in the independent data set. PD-Ls expression significantly correlated with FOXP3+ lymphocyte infiltration. Moreover, tumorinfiltrating $\mathrm{PD} 1^{+} \mathrm{CD}^{+}$cytotoxic cells and T-reg cells were also independent prognostic factorsfor overall survival (OS) and post operative recurrence. [22]. However, it should be considered that, until today, the biological bases of pathogenesis/progression of HCC remain poorly defined. Figure 1 describes the principal pathogenetic mechanisms of immune-tolerance involved in HCC.

\section{INTERACTION BETWEEN ANTI- VEGF THERAPY AND HCC IMMUNOSURVEILLANCE}

Vascular endothelial growth factor (VEGF)/ VEGF receptor (VEGFR) axis, one of the most important molecular pathways controlling angiogenesis, plays a key role in tumor microenviroment including immunosupression. VEGF is known to inhibit DCs maturation through the activation of NF-KB which is able to influence the differentiation of monocytes into DCs. In addition, VEGF promotes an immunosuppressive phenotype both increasing the DCs production of IDO, a strong inhibitor of T-cell activation, as well as inactivating STAT3 [23]. Interestingly, Motz et al. reported that VEGF could induce Fas Ligand expression in tumor endothelial cells, inhibiting cytotoxic T-lymphocyte (CTL) infiltration in the tumor and reducing their cytotoxic activity [24]. 
Table 1: Combination of anti-angiogenetictherapy and immunotherapy clinical trials

\begin{tabular}{|c|c|c|c|c|c|}
\hline Phase & Anti-angiogenesis drug & $\begin{array}{l}\text { Immunecheckpoints } \\
\text { blocker }\end{array}$ & Design & Primary endpoint(s) & Clinical trail ID \\
\hline I & $\begin{array}{l}\text { Angiokinase inhibitor } \\
\text { targeting VEGFR 1-3, } \\
\text { FGFR 1-3, and PDGFR A/B } \\
\text { (nintedanib) }\end{array}$ & $\begin{array}{l}\text { IGG4 anti-PD-1 blocking } \\
\text { mAb (pembrolizumab) }\end{array}$ & $\begin{array}{l}\text { Pembrolizumab }+ \\
\text { nintedanib (PEMBIB) } \\
\text { in second line HCC }\end{array}$ & $\begin{array}{l}\text { Maximum tolerated } \\
\text { dose and dose limiting } \\
\text { toxicities }\end{array}$ & NCT02856425 \\
\hline I & $\begin{array}{l}\text { Anti-VEGFR2 } \\
\text { (ramucirumab) }\end{array}$ & $\begin{array}{ll}\text { Anti-PD-L1 } & \text { immune } \\
\text { checkpoint } & \text { inhibitor } \\
(M E D I 4736) & \end{array}$ & $\begin{array}{l}\text { Ramucirumab } \\
+\quad \text { MEDI4736 in } \\
\text { metastatic or locally } \\
\text { advanced } \\
\text { unresectable HCC and }\end{array}$ & Dose limiting toxicities & NCT02572687 \\
\hline $\mathrm{I} / \mathrm{II}$ & VEGFR2-TKI (apatinib) & $\begin{array}{l}\text { Anti-PD-1 mAb (SHR- } \\
1210)\end{array}$ & $\begin{array}{l}\text { Apatinib }+ \\
\text { SHR-1210 in advanced } \\
\text { HCC }\end{array}$ & Overall survival rate & NCT02942329 \\
\hline III & VEGFR -TKI (sorafenib) & $\begin{array}{l}\text { Pexastimogene } \\
\text { devacirepvec }(\text { Pexa-Vec })\end{array}$ & $\begin{array}{l}\text { Sorafenib VS sorafenib } \\
+ \text { Pexa-Vac in advanced } \\
\text { HCC }\end{array}$ & Overall survival & NCT02562755 \\
\hline
\end{tabular}

Abbreviation - FGFR: fibroblast growth factor receptor; HCC: hepatocellular carcinoma; mAb: monoclonal antibody; PDGFR: platlet derived growth factor receptor; TKI: tyrosin kinase inhibitor; VEGFR: vascular endothelial growth factor receptor.

Voron et al., on the other hand, showed that VEGF induces exhaustion in intratumoral CD8 $+\mathrm{T}$ cells by promoting the expression of PD-1 and other checkpoint molecules such us CTLA-4 and TIM-3 [25]. Myeloid-derived suppressor cells (MDSCs) were shown to inhibit NK cell activation though TGF- $\beta$ and NK protein 30 and to regulate T-cell proliferation by L-arginine. Intratumoral MDSCs infiltration correlates with circulating VEGF levels in several solid tumors, including HCC [26]. Furthermore, injection of recombinant VEGF increased MDSC population in vivo, and liver-specific overexpression of VEGF led to accumulation of proangiogenic MDSCs in a SDF1 $\alpha /$ CXCR4 pathway-dependent manner [27].

In line with these data, anti-VEGF treatment may have potential immune-modulatory functions. Sorafenib, the first therapy approved in advanced HCC stage, exerts its activity by a pan-VEGF receptor inhibition. Preclinical studies in liver cancer models showed that sorafenib decreases MDSC and T-reg levels in spleen, bone marrow and tumor, restraining their function as well [28]. Nevertheless, sorafenib seems to decrease IL-12 expression and to impair DCs function [29]. At the same time, excessive pruning of tumor vasculature over time could aggravate hypoxia in the tumor microenviroment, resulting in high hypoxia-inducible factor- $1 \alpha$ (HIF)- $1 \alpha$ levels, which enhances immune checkpoint molecules expression such as PD-L1 in MDSCs and macrophages [30].

Chen et al. examined the effects of implementing anti-PD1 monoclonal antibody $(\mathrm{mAb})$ to sorafenib in mice with HCC. The increased hypoxia after sorafenib resulted in increased intratumoral levels of PDL-1 and up-regulation of SDF $1 \alpha / \mathrm{CXCR}-4$ pathway with a consequent accumulation of immunosuppressive cells. Anti-PD-1 mAb administration did not significantly delay tumor growth when combined with sorafenib alone, even if the combination of an anti-PD-1 with sorafenib and AMD3100, an anti-CXCR-4 molecule, notably restrained tumor growth and metastasis [31].

According to these results, a potential future approach could be represented by a careful titration of VEGF inhibition with the aim to block the VEGF pathway and contemporarily alleviate hypoxia by vascular normalization, enhancing immunotherapy efficacy [32]. Trials evaluating a combined approach comprising antiangiogenesis drugs and immunotherapy are currently ongoing (Table 1).

\section{HCC IMMUNE-RESPONSE STRATEGIES}

There are three main strategies to improve tumorspecific immune response (Figure 2): i) adoptive immunotherapy - HCC-epitopes immunized cells, which recognize and act against cancer cells; ii) indirect immunological strategies - cytokines, immune checkpoint blockade mAbs, cancer vaccines used to increase immune system activity; iii) indirect non immunological strategies - antigen-encoding mRNA strategy in HCC, metronomic chemotherapy, oncolytic viruses [33]. Table 2 summarises the main clinical trials and restrospective studies or metaanalysis in HCC immunotherapy. 


\section{ADOPTIVE IMMUNOTHERAPY}

Adoptive immunotherapy utilizes NK and cytokine induced killer (CIK) cells for autologous cells reinfusion immunized with cancer epitopes. NK cells are immune lymphocytic cells resident in reticuloendothelial organs with a key role in immune and anti-tumor defense [34].

Thirty-seven HCC patients treated with radiofrequency ablation (RFA) showed a phenotypic and functional activation of autologous NK-cells [35].
Currently, adjuvant autologous NK cell reinfusion is being evaluated in 2 ongoing clinical studies in transplant and resected patients ( NCT01147380 [36] and NCT02008929 [37]).

CIK cells are a heterogeneous cell population comprising $\mathrm{CD} 3+\mathrm{CD} 56+, \mathrm{CD} 3+\mathrm{CD} 56-$ and CD3CD56+ cells, which are able to both recognize tumor antigens and kill cancer cells directly [38]. Several studies reported an improved outcome, using CIK cells as adjuvant therapy after liver surgery in HCC patients. In

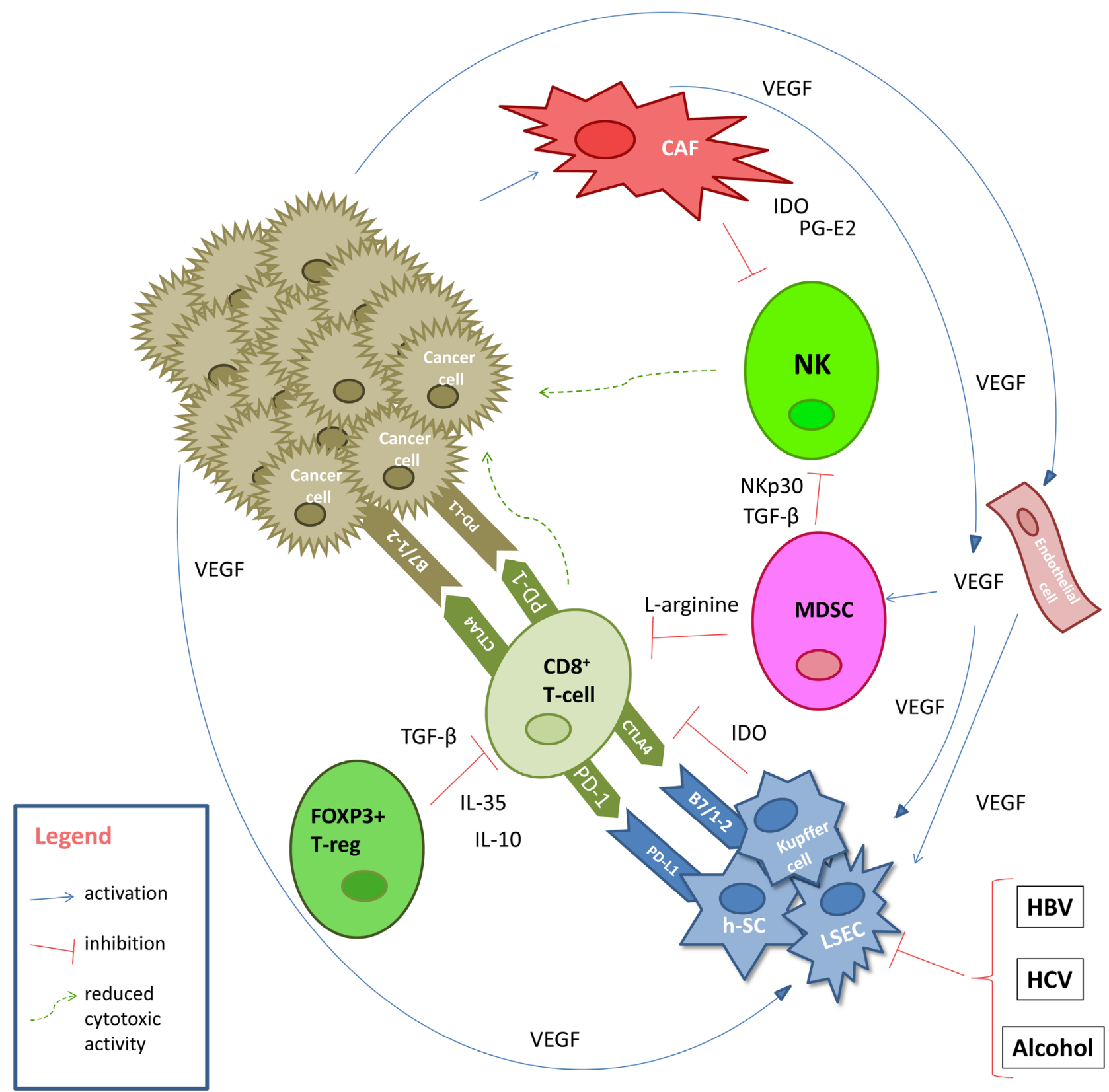

Figure 1: Pathogenetic mechanisms of immune-tolerance in HCC. Abbreviation - CAF: cancer associated fibroblast; CTLA4: cytotoxic T-limphocite antigen-4; HBV: hepatits B virus; HCV: hepatits C virus; h-SC: hepatic stellate cells; IDO: indoleamine 2,3 dioxygenase; IL: interleukin; LSEC: liver sinusoidal endothelial cells; MDSC: myeloid-derived suppressor cells; NK: natural killer; NKp30: natural killer protein 30; PD-1:programmed cell death protein 1; PD-L1: programmed cell death protein ligand 1; PG-E2: prostaglandin E2; TGF- $\beta$ : transforming growth factor $\beta$; VEGF: vascular endothelial growth factor. 
particular, a phase II study evaluating the adjuvant role of CIK cells considered $127 \mathrm{HCC}$ radically resected patients which were randomized into the following 3 arms: 3 or 6 courses of adjuvant CIK cells infusion immunotherapy or observation only. Disease free survival (DFS) rate at 1,3 , and 5 -year was $83.1 \%, 31.7 \%$, and $23.3 \%$ in 3 courses CIK cell infusion, $84.7 \%, 30.5 \%$, and, $19.4 \%$ in 6 courses CIK cell infusion, and $82.6 \%, 20.9 \%$, and $11.2 \%$ in the control group, respectively. A statistically significant difference between 3 courses CIK cells $(p=0.001)$ and 6 courses CIK cells $(p=0.004)$ as compared to the control group was observed in the absence of a statistically difference between CIK cell groups [39]. Similarly, a large retrospective study comparing surgery alone (206 patients) with surgery followed by CIK cell transfusion (204 patients) showed a significantly better prognosis in the CIK group. The 1-, 2-, 3-, 4-, and 5-year OS rates of CIK group were higher than surgery alone group: $93.6 \%$, $83.3 \%, 76.6 \%, 71.1 \%, 65.9 \%$ and $84 \%, 69.2 \%, 61.6 \%$, $56.9 \%, 50.2 \%$, respectively, with a significant difference between the two groups (log-rank test; $p=0.0007$ ). Moreover, patients treated with more than 8 cycles of cell transfusion showed significantly better survival than those treated with less than 8 cycles $(p=0.0272)$. CIK group displayed significantly better OS than surgery-alone group in patients with more than 5-cm tumors $(\mathrm{p}=0.0002)$ [40].

Another retrospective study compared 85 patients treated with adoptive autologous CIK cell transfusion in combination with transarterial chemoembolization (TACE) plus RFA, versus 89 patients treated with locoregional therapy alone. Despite similar response rates, the TACE+RFA+CIK cell group showed a significant improvement in terms of longer progression free survival (PFS) (17 months versus 10 months, $p=0.001)$ and OS (56 months versus 31 months, $p=0.001$ ) compared to the TACE+RFA group [41]. Recently, in a multicenter phase III study, $230 \mathrm{HCC}$ patients treated by surgery, RFA or percutaneous ethanol injection were randomized to receive adjuvant autologous CIK cells infusion or not, showing a median DFS of 44 months and 30 months, respectively ( $p$ $=0.010$ by 1 -sided log-rank test) [42]. A meta-analysis, including 13 phase II/III trials evaluating the use of the CIK cell adjuvant after RFA and TACE, demonstrated a significantly improved 1 -year OS (OR $=0.25,95 \% \mathrm{CI}$ : 0.12 to $0.52, p<0.001)$ and 2 -year $\mathrm{OS}(\mathrm{OR}=0.17,95 \%$ CI: 0.07 to $0.43, p<0.001)$ [43]. Finally, a systematic

\section{Adoptive immunoterapy \\ NKs

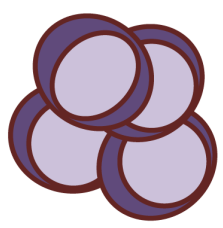 CIKs
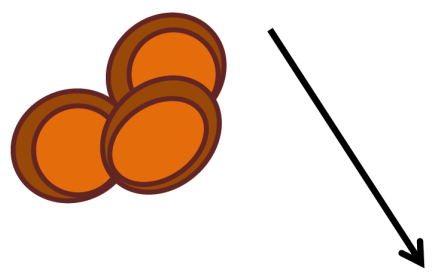

Indirect immulogical strategies cytokines

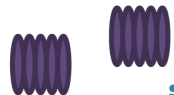

immunecheckpoints

non-immulogical strategies

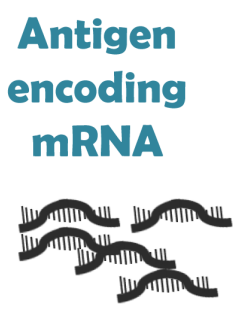

Oncolytic virus

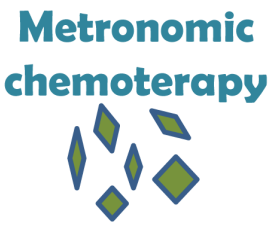

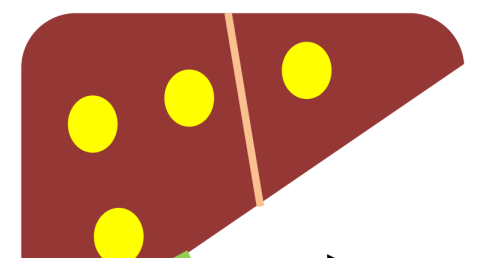

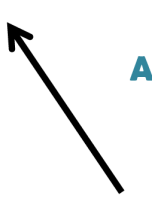

Antigen-pulsed DCs

vaccines
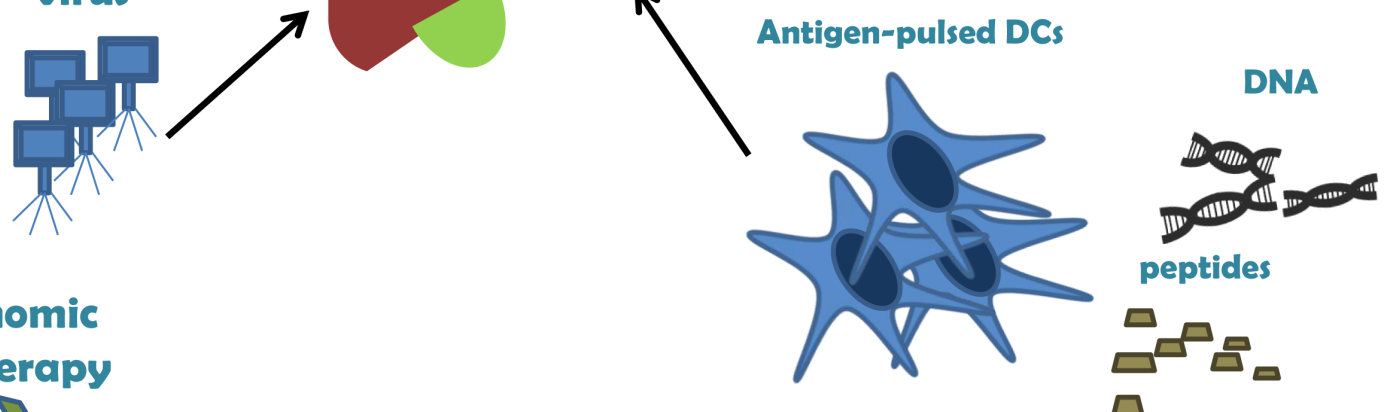

Figure 2: The three main strategies of HCC immunotherapy 
Table 2: Clinical trials and retrospective studies or meta-analysis in immunotherapy treatments of HCC

\begin{tabular}{|c|c|c|c|c|}
\hline $\begin{array}{l}\text { Immune-therapy } \\
\text { strategies }\end{array}$ & Trial/study & Design & Results & Ref. \\
\hline \multirow{5}{*}{ Adoptive immunotherapy } & $\begin{array}{l}\text { Randomized phase } \\
\text { II }\end{array}$ & $\begin{array}{l}\text { Adjuvant } 6 \text { versus } 3 \text { courses of } \\
\text { CIK cell infusion immunotherapy } \\
\text { in resected patients }\end{array}$ & $\begin{array}{l}\text { 1-, } 3-, 5-y \text { - DFS rates } \\
6 \text { courses CIK infusion: } 84.7 \%, 30.5 \%, 19.4 \% \\
3 \text { courses CIK infusion: } 83.1 \%, 31.7 \%, 23.3 \%\end{array}$ & 39 \\
\hline & $\begin{array}{l}\text { Retrospective } \\
\text { analysis }\end{array}$ & $\begin{array}{l}\text { Adjuvant CIK } \\
\text { immunotherapy } \\
\text { patients }\end{array}$ & $\begin{array}{l}\text { 1, } 2,3,4,5 \text {-y OS rates } \\
\text { Untreated group: } 84 \%, 69.2 \%, 61.6 \%, 56.9 \% \text {, } \\
50.2 \% \\
\text { CIK cells group: } 93.6 \%, 83.3 \%, 76.6 \% \text {, } \\
71.1 \%, 65.9 \%\end{array}$ & 40 \\
\hline & $\begin{array}{l}\text { Retrospective } \\
\text { analysis }\end{array}$ & $\begin{array}{l}\text { Adjuvant autologous CIK cell } \\
\text { infusion immunotherapy versus } \\
\text { control after locoregional } \\
\text { procedures }\end{array}$ & $\begin{array}{l}\text { Overall RRs: } 79.8 \% \text { versus } 76.5 \% \\
\text { OS: } 56 \text { months versus } 31 \text { months } \\
\text { PFS: } 17 \text { months versus } 10 \text { months }\end{array}$ & 41 \\
\hline & Phase III & $\begin{array}{l}\text { Adjuvant activated CIK cells } \\
\text { infusion immunotherapy versus } \\
\text { control in resected patients or } \\
\text { after RFA or after percutaneous } \\
\text { ethanol injection }\end{array}$ & mDFS: 44 months versus 30 months & 42 \\
\hline & $\begin{array}{l}\text { Meta-analysis } \\
\text { including } 13 \text { phase } \\
\text { II/III trials }\end{array}$ & $\begin{array}{l}\text { Adjuvant activated CIK cells } \\
\text { infusion immunotherapy after } \\
\text { RFA and/or TACE }\end{array}$ & $\begin{array}{l}1-y \text { OS }-\mathrm{OR}=0.25(95 \% \mathrm{CI}, p<0.001) \\
2-\mathrm{y} \text { OS }-\mathrm{OR}=0.17(95 \% \mathrm{CI}, p<0.001)\end{array}$ & 43 \\
\hline \multirow{11}{*}{$\begin{array}{l}\text { Indirect immunological } \\
\text { strategies }\end{array}$} & $\begin{array}{l}\text { Randomized phase } \\
\text { II }\end{array}$ & $\begin{array}{l}\text { TACE plus IFN- } \alpha \text { versus TACE in } \\
\text { unresectable HCC }\end{array}$ & $\begin{array}{l}\text { mOS: } 29 \text { months versus } 26 \text { months } \\
(p=0.003) \\
\text { mDFS: } 23.6 \text { months versus } 20.3 \text { months } \\
(p=0.027)\end{array}$ & 51 \\
\hline & Phase II & $\begin{array}{l}\text { Combined intrarterial 5-FU plus } \\
\text { PEG-IFN } \alpha \text {-2b in advanced HCC } \\
\text { with portal venous invasion }\end{array}$ & $\begin{array}{l}\text { ORR: } 73 \% \\
\text { mOS: } 29.9 \text { months }\end{array}$ & 52 \\
\hline & $\begin{array}{l}\text { Meta-analysis of } \\
10 \text { trials }\end{array}$ & Adjuvant IFN versus placebo & $\begin{array}{l}\text { Recurrence rate - OR: } 0.42(\text { CI 95\%; } p< \\
0.00001)\end{array}$ & 53 \\
\hline & Phase I & Tremelimumab in advanced HCC & $\begin{array}{l}\text { Good toxicity profile } \\
\text { PR: } 17.6 \% \\
\text { SD: } 45 \%\end{array}$ & 58 \\
\hline & Phase I/II & Nivolumab in advanced HCC & $\begin{array}{l}\text { Good toxicity profile } \\
\text { ORR: } 20 \% \\
\text { Median duration of response: } 9.9 \text { months }\end{array}$ & 62 \\
\hline & Phase I & $\begin{array}{l}\text { Pulsed DCs by autologous cells } \\
\text { from tumor lysate in advanced } \\
\text { HCC }\end{array}$ & $\begin{array}{l}\text { Positive feasibility } \\
\text { Low toxicity profile }\end{array}$ & 70 \\
\hline & Phase II & $\begin{array}{l}\text { DCs pulsed with HepG2 cell } \\
\text { lysate in advanced HCC }\end{array}$ & $\begin{array}{l}\text { DCR: } 28 \% \\
\text { Low toxicity profile }\end{array}$ & 71 \\
\hline & Phase I & $\begin{array}{l}\text { AFP-derived vaccine in advanced } \\
\text { HCC }\end{array}$ & T-cell increased activity in all patients & 74 \\
\hline & Phase I & $\begin{array}{l}\text { GPC3 vaccine } \\
\text { advanced HCC }\end{array}$ & $\begin{array}{l}\text { mOS: } 12.2 \text { months in high T-cell expressing } \\
\text { patients } \\
\text { mOS: } 8.5 \text { months in low expressing patients }\end{array}$ & 75 \\
\hline & Phase II & $\begin{array}{l}\text { Telomerase peptide GV1001 } \\
\text { vaccine in advanced HCC }\end{array}$ & $\begin{array}{l}\text { Low toxicity profile } \\
6 \text { mo SD: } 45.9 \% \\
\text { mTTP: } 57 \text { days } \\
\end{array}$ & 78 \\
\hline & Phase II & $\begin{array}{ll}\begin{array}{l}\text { Second line therapy with } \\
\text { lenalidomide }\end{array} & \\
\end{array}$ & $\begin{array}{l}\text { OS: } 7.6 \text { months } \\
\text { PR: } 15 \%\end{array}$ & \\
\hline \multirow[t]{2}{*}{\begin{tabular}{c|} 
Indirect non \\
immunological strategies
\end{tabular}} & Phase II & $\begin{array}{l}\text { Metronomic capecitabine in } \\
\text { previously untreated and resistant } \\
\text { to/intolerant of sorafenib } \\
\text { advanced HCC }\end{array}$ & $\begin{array}{l}\text { mPFS (untreated): } 6 \text { months } \\
\text { mPFS (second line): } 14.4 \text { months }\end{array}$ & 89 \\
\hline & $\begin{array}{l}\text { Randomized phase } \\
\text { II }\end{array}$ & $\begin{array}{l}\text { Two doses of JX-594 (high } \\
\text { versus low dose) vaccinia virus in } \\
\text { advanced HCC }\end{array}$ & $\begin{array}{l}\text { Positive feasibility } \\
\text { mOS: } 14.1 \text { versus } 6.7 \text { months }\end{array}$ & 90 \\
\hline
\end{tabular}

Abbreviation - CI: confidence interval; CIK: cytokine induced killer; DC: dendritic cell; DCR: disease control rate; DFS: disease free survival; HCC: hepatocellular carcinoma; IFN: interferon; mDFS: median disease free survival; mOS: median overall survival; mTTP: median time to progression; ORR: overall response rate; OS: overall survival; PFS: progression free survival; PR: partial response; RFA: radiofrequency ablation; RR: recurrence rate; SD: stable disease; TACE: transarterial chemoembolization. 
review of the literature, including 14 eligible articles, confirmed that CIK cells could prevent recurrence in resected HCC [44]. Currently, several phase III/IV studies are ongoing on autologous CIK cell infusion adjuvant therapy. NCT01749865 [45] and NCT00769106 [46] are two phase III studies which will assess time to recurrence after surgery as the primary end-point in HCC patients who underwent to radical resection.

In conclusion, the adoptive immunotherapy achieved favorable results in particular in the adjuvant setting leading to these last phase III trials in HCC.

\section{INDIRECT IMMUNOLOGICAL STRATEGIES}

\section{Interferons}

Recombinant human IFN- $\alpha$ was the first immunotherapy to undergo substantial clinical development in $\mathrm{HCC}$, due to the extensive experience gained in the treatment of chronic viral hepatitis as well as to its anti-angiogenic and immunostimolatory proprieties [47]. In vitro studies showed a pro-apoptotic effect of IFN- $\alpha$, IFN- $\beta$, and IFN- $\gamma$ on HCC cells [4850]. A phase II randomized trial comparing TACE plus IFN- $\alpha$ versus TACE in unresectable HCC showed median DFS of 23.6 months and 20.3 months in TACE-IFN- $\alpha$ and TACE groups, respectively $(p=0.002)$. mOS of 29 months and 26 months were observed in the TACE-IFN- $\alpha$ and control group, respectively $(p=0.003)$ [51]. A phase II trial evaluating the efficacy of combined intrarterial 5-fluorouracil (5-FU) and systemic pegylated IFN $\alpha-2 b$ in patients with advanced HCC with portal venous invasion reported mOS of 29.9 months [52]. A meta-analysis of 10 trials (8 randomized and 2 non-randomized controlled studies) demonstrated that recurrence rate (RR) was significantly lower in patients treated with adjuvant IFN with respect to the placebo group $(\mathrm{OR}=0.66 ; 95 \% \mathrm{CI}$ $=0.50$ to $0.86 ; p=0.02)$. Death rates were significantly decreased $(\mathrm{OR}=0.42 ; 95 \% \mathrm{CI}=0.32$ to $0.56 ; p<$ $0.00001)$ and subgroup analysis showed an advantage for the group treated with TACE $(\mathrm{OR}=0.33 ; 95 \% \mathrm{CI}=0.21$ to $0.50 ; p<0.00001)$ compared to patients treated with surgery $(\mathrm{OR}=0.51 ; 95 \% \mathrm{CI}=0.36$ to $0.72 ; p=0.0002)$ [53]. An in vivo study demonstrated that sorafenib in combination with IFN synergistically suppressed tumor growth, inducing apoptosis [54]. An ongoing, phase II randomized trial is comparing IFN- $\alpha$ plushepatic arterial infusion 5-FU versus cisplatin plus 5-FU in $\mathrm{HCC}$ patients after liver resection (NCT01834963) [55].

\section{Immune checkpoint inhibitors}

Several negative immunologic regulator targets revolutionized cancer care in melanoma, renal cancer, and non small cell lung cancer with significant improvement in terms of mOS and response rate [56]. CTLA-4 and PD-1 are the most studied immune checkpoint inhibitors in HCC [57].

Tremelimumab, an anti-CTLA-4 mAb, has been tested in a phase I trial recruiting 21 advanced $\mathrm{HCC}$ patients. This molecule was well tolerated with $17.6 \%$ and $58.8 \%$ of partial response (PR) and stable disease , respectively. Interestingly, an over 200 -fold decrease of serum viral load in $12 \mathrm{HCC} \mathrm{HCV}$ infected patients treated with tremelimumab has been seen [58]. A phase I trial of tremelimumab in combination with RFA or TACE has been concluded (NCT01853618) [59]. This combined therapy proved to be safe and of the 10 patients evaluable for response outside loco-regional treatments, all showed immune cell infiltration and 4 achieved confirmed PR [60].

Nivolumab, a fully human $\mathrm{mAb}$ anti-PD-1 has been tested in advanced HCC patients in the CheckMate 040 study. It presented a fairly good toxicity profile with a $20 \%$ of response rate in 214 patients treated in the dose expansion phase. Median duration of response was 9.9 months with a disease control rate (DCR) of $64 \%$. Moreover, 9-months OS rate in the expansion phase was 74\% (95\% CI 67-79) [61].

Preliminary studies evaluating the role of MEDI4736, an anti PD-L1 mAb, suggested a favoreable toxicity profile with a DCR at 12 weeks of $21 \%$ [62].

The study protocols of two clinical trials involving the anti-PD-1 mAb pembrolizumab have been recently presented at ASCO 2017 Gastrointestinal Cancers Symposium. The former is a single-arm, multicentric, phase 2 study (KEYNOTE-224) designed to evaluate the efficacy and safety of pembrolizumab in previously treated advanced HCC patients. [63]. The latter is a double-blind, placebo-controlled phase 3 study (KEYNOTE-240) which will randomize pembrolizumab versus placebo in previously treated advanced HCC [64].

In a murine melanoma vaccine model, inhibition of both CTLA-4 or PD-1 increased the proportion of CTLA4 and $\mathrm{PD}-1$-expressing CD4/CD8 tumor infiltrating $\mathrm{T}$ effector cells and decreased intratumoral $\mathrm{T}$ regulatory cells, as compared to either agent alone [65]. Given the increased efficacy observed with combination approaches in other tumor types, the Checkmate 040 trial will evaluate the efficacy and toxicity of the combination of ipilimumab plus nivolumab (NCT01658878) [66].

Currently, several anti-immunocheckpoint inhibitor mAbs are being developed (Table 3). These drugs are radically changing the approach to oncological diseases, being able to offer both a longer duration of response and a better toxicity profile compared to chemotherapy or target therapy. Nevertheless, the economic impact of these drugs 
Table 3: Clinical trials of immune-checkpoint blocker in HCC patients

\begin{tabular}{|c|c|c|c|c|c|c|}
\hline $\begin{array}{l}\text { Immune- } \\
\text { checkpoints } \\
\text { target }\end{array}$ & Drug & $\begin{array}{l}\text { Associated } \\
\text { treatment }\end{array}$ & Phase & Status & Results & Clinical trial ID \\
\hline \multirow[b]{2}{*}{ CTL-A4 } & Tremelimumab & None & II & Completed & PR: $17.6 \%$; SD: $58.8 \%$ & NCT01008358 \\
\hline & Tremelimumab & TACE or ablation & I & Recruiting & $\begin{array}{l}\text { mPFS for study } \\
\text { population }(\mathrm{n}=17) \text { : } \\
7.4 \text { months }\end{array}$ & NCT01853618 \\
\hline \multirow{2}{*}{ PD-L1/CTL-A4 } & $\begin{array}{l}\text { Durvalumab/ } \\
\text { Tremelimumab }\end{array}$ & TACE or RFA & $\mathrm{I} / \mathrm{II}$ & Recruiting & NA & NCT02821754 \\
\hline & Nivolumab/Ipilimumab & None & $\mathrm{I} / \mathrm{II}$ & Recruiting & NA & NCT01658878 \\
\hline \multirow{6}{*}{ PD-1 } & Nivolumab & $\begin{array}{l}\text { TGFBR1 } \\
\text { kinase inhibitor } \\
\text { (galunisertib) }\end{array}$ & $\mathrm{I} / \mathrm{II}$ & Recruiting & NA & NCT02423343 \\
\hline & Nivolumab & None & $\mathrm{I} / \mathrm{II}$ & Recruiting & $\begin{array}{l}\text { Good toxicity profile; } \\
\text { response rate: } 20 \% \text {; } \\
\text { median duration of } \\
\text { response: } 9.9 \text { months }\end{array}$ & CA209-040 \\
\hline & $\begin{array}{l}\text { Anti-PD-1 antibody } \\
\text { (not specified) }\end{array}$ & Decitabine & $\mathrm{I} / \mathrm{II}$ & Recruiting & NA & NCT02961101 \\
\hline & Pembrolizumab & None & II & Recruiting & NA & NCT02702414 \\
\hline & PDR001 & $\begin{array}{l}\text { c-met inhibitor } \\
\text { (INC280) }\end{array}$ & II & Recruiting & NA & NCT02795429 \\
\hline & PDR001 & $\begin{array}{l}\text { Anti-TGF beta } \\
\text { antibody (NIS793) }\end{array}$ & II & $\begin{array}{l}\text { Not } \quad \text { yet } \\
\text { recruting }\end{array}$ & NA & NCT02947165 \\
\hline
\end{tabular}

Abbreviation-CR: complete response; CTLA4: receptor and cytotoxic T-limphocite antigen-4; RFA: radiofrequency ablation; PD-1: programmed cell death protein 1; PD-L1: programmed cell death ligand1; PR: partial response; SD: stable disease; TACE: transarterial chemoembolization.

will force clinicians and researchers to select patients who should be elegible for these treatments. In this scenario, the identification of biomarkers able to predict the response to checkpoint blockades represents an intriguing area of research. Immunohistochemical evaluation of PDL1 is a tested predictive biomarker for the response to PD-1/PD-L1 mAbs. Indeed, the histological detection of tumor infiltration of immune cells or their molecules in the tumor microenvironment may be indirect predictive biomarkers of response to PD-1/PD-L1 checkpoint blockades. Moreover, mismatch-repair deficiency gene analysis should improve the clinical benefit of immune checkpoint inhibitors [67].

\section{Vaccine strategy}

The aim of cancer vaccination is the induction and continuance of a tumor-specific immune response by eliciting effector $\mathrm{T}$ cells that can specifically decrease tumor load and control tumor relapse. Various approaches have been used in this setting: i) pulsed DCs , ii) peptidebased vaccines, and iii) DNA-based vaccines.
DCs play a key role in both innate and adaptive immunity. They resulted increased in peripheral blood and lymph nodes of HCC patients [68]. Moreover, DC infiltration in HCC lesions has been associated with a better prognosis in resected patients [69]. A phase I trial showed a feasible and well tolerated anti-cancer immunization through the stimulation of DCs by autologous cells from HCC lysate [70]. A phase II trial with DCs pulsed with HepG2 cell lysate demonstrated a DCR of $28 \%$ in the absence of relevant adverse events in 39 advanced HCC patients [71]. Finally, in 20 and 13 HCC patients treated with TACE and TACE followed by DC infusion, respectively, a more effective enhancement of tumor specific immune response with the combination approach was observed, without differences in terms of RR [72]. An ongoing phase I trial is evaluating the administration of intra-tumoral DC allogenic vaccine (NCT01974661) [73]. The external passive immunization of these patients with reinfusion of DCs able to develop an immune response against tumor cells could be a feasible and active strategy even if the complexity of the process may represent a key challenge. 
$\alpha \mathrm{FP}$ and glypican-3 (GPC3) are the main HCC tumor associated antigens of peptide-based vaccine. $\alpha \mathrm{FP}$-derived vaccine has been evaluated in a phase I trial reporting a T-cell increased specific activity in all patients [74]. Another phase I trial involving 33 advanced HCC patients treated with GPC3 vaccine reported a mOS of 12.2 months $(95 \% \mathrm{CI}=6.5-18.0)$ and 8.5 months $(95 \%$ $\mathrm{CI}=3.7-13.1)(p=0.033)$ in patients with a high GPC3related CTLs expressionand in those with a low GPC3related CTL expression, respectively [75].

Recently, a promising ongoing phase II trial (UMINCTR: 000002614) is evaluating GPC3 vaccine after surgery or RFA [76]. Currently, preclinical data for GPG3 DNA-based vaccines indicated the induction of specific and effective cellular antitumor immunity against GPC3 only in in vivo models [77]. No clinical trials are ongoing even if a report of two pretreated $\alpha \mathrm{FP}$ positive HCC patients treated with $\alpha$ FP-DNA vaccine and adenovirus driven immunization showed promising safety and immunogenic $\mathrm{T}$ cell response [78]. Although it was not a characteristic antigen, the telomerase peptide GV1001 was evaluated in a clinical phase II trial with a median TTP of 57 days [79]. Another therapeutic strategy potentially able to improvethe clinical outcome of these patients could be the combination of vaccination with anti-angiogenic tyrosine-kinase inhibitors (TKIs), such as sorafenib [80]. Regarding this, an ongoing phase III trial is comparing vaccinia virus based immunotherapy plus sorafenib versus sorafenib alone (PHOCUS) (NCT02562755) [81].

Vaccines have been the first therapeutic strategy in immuno-oncology. Anyway, after decades of studies, despite the fact that some positive data are available in literature, there are no phase III trials to prompt this approach in HCC.

\section{Immunomodulator strategy}

Initial data regarding the activity of immunomodulators in $\mathrm{HCC}$ treatment are currently avaiable. Lenalidomide has been evaluated in a phase II study after sorafenib failure or intolerance, with PR of $15 \%$ and 7.6 months of mOS [82]. In an orthotopic HCC model, lenalidomide plus sorafenib showed an interesting tumor growth inhibition, with a significant increase of $\mathrm{T}$ cytotoxic IFN- $\gamma$ infiltrating tumor cells [83]. Further data are mandatory in this therapeutic setting.

\section{INDIRECT NON IMMUNOLOGICAL STRATEGIES}

\section{Antigen-encoding mRNA strategy}

Another recent vaccination strategy is represented by the antigen-encoding mRNA technique. mRNA encodes genetic information corresponding to whole antigens, with a consequent antigen expression and presentation. This approach is not associated to the risk of genomic integration, with a more favorable safety profile compared to the use of DNA sequences. On one hand, DCs can be cultivated and electroporated with mRNA followed by their restitution into the patient. On the other, "nude mRNA" can be injected intratumorally. In both cases antitumour immune responses were achieved in a variety of mouse models $[84,85]$. Lastly, a recent study is evaluating the role of TriMix mRNA and mRNA encoding the target antigens GPC3 and MAGE-C2 mRNA when injected intranodally the same day as the RFA treatment [86].

\section{Metronomic chemotherapy}

Metronomic chemotherapy is the admnistration of low-dose chemoterapeutic drug for a long period in the absence of drug-freebreaks [87].

Several Authors demonstrated that tumor response to this therapeutic approach is related not only to a direct antineoplastic activity but also to the following immune-stimulatory: i) activation of immunity, ii) induction of tumor dormancy, and iii) chemotherapydriven dependency of cancer cells [88]. An Italian, phase II non-randomized trial included 59 previously untreated patients with advanced $\mathrm{HCC}$ and 31 patients resistant to or intolerant of sorafenib treated with capecitabine $500 \mathrm{mg}$ twice daily until progression of disease or unacceptable toxicity. [89]. Authors reported mPFS of 6 months and 14.4 months in the two cohorts, respectively. Treatment was well tolerated with an acceptable toxicity. Anyway, no immunological analyses have been performed in this trial.

\section{Oncolytic viruses}

Oncolytic viruses have a dual mechanism of action. In fact, they are able to induce both tumor cells lysis during viral replication and unmasking of tumor antigens for cell-mediated activation. A randomized phase II trial tested the feasibility of two doses of JX-594 (Pexa-Vec), an oncolytic and immunotherapeutic vaccinia virus in 30 HCC patients. Treatment was well tolerated with flu-like symptoms, anorexia, lymphopenia, and hypertransaminasemia, and a significantly longer mOS in high-dose arm respect to low-dose arm (14.1 months and 6.7 months, respectively) [90]. On the contrary, JX-594 did not extended mOS with respect to best supportive care in second line therapy after sorafenib [91]. Currently, a phase III study is randomizing the administration of this virus followed by sorafenib versus sorafenib alone in advanced HCC untreated patients (NCT02562755) [81]. 


\section{CONCLUSIONS}

Today, sorafenib and regorafenib are the only therapies that have shown efficacy in advanced HCC. New molecular approaches have been experimented, without significant improvement of survival. Therefore, we urgently need to identify new therapeutic strategies as well as to select patients suitable for these treatments. Immunotherapy is laying the foundations for solid treatments. In recent years different clinical studies examining the role of immunotherapy to treat HCC have been conducted with initial promising results in particular regarding CIK cells in the adjuvant setting and immune checkpoint inhibitors in advanced stages. The results of the several ongoing trials are warranted. Furthermore, since the hepatic immune system plays an important role in reduction ofthe immune response, the possibility of unmasking these mechanisms seems to be a winning weapon in HCC, with immunotherapy playing a fundamental role in this cancer in the near future.

\section{ACKNOWLEDGMENTS}

We sincerely thank Bianca Tino a native English speaker for the language revision.

\section{CONFLICT OF INTEREST}

The Authors declare the absence of conflict of interests.

\section{REFERENCES}

1. Siegel RL, Miller KD, Jemal A. Cancer statistics, 2016. CA Cancer J Clin. 2016; 66: 7-30.

2. Gomaa AI, Khan SA, Toledano MB, Waked I, TaylorRobinson SD. Hepatocellular carcinoma: Epidemiology, risk factors and pathogenesis. World Journal of Gastroenterology. 2008; 14: 4300-4308.

3. Villanueva A, Hernandez-Gea V, Llovet JM. Medical therapies for hepatocellular carcinoma: a critical view of the evidence. Nature Review Gastroenterology Hepatology. 2013; 10: 34-42.

4. Chan SL, Mok T, Ma BB. Management of hepatocellular carcinoma: beyond sorafenib. Current Oncology Report. 2012; 14: 257-266.

5. Gnoni A, Santini D, Scartozzi M, Russo A, Licchetta A, Palmieri V, Lupo L, Faloppi L, Palasciano G, Memeo V, Angarano G, Brunetti O, Guarini A, et al. Hepatocellular carcinoma treatment over sorafenib: epigenetics, microRNAs and microenvironment. Is there a light at the end of the tunnel? Expert Opinion Therapeutic Targets. 2015; 27: 1-13.

6. Bruix J, Qin S, Merle P, Granito A, Huang YH, Bodoky G, Pracht M, Yokosuka O, Rosmorduc O, Breder V, Gerolami
R, Masi G, Ross PJ, et al. Regorafenib for patients with hepatocellular carcinoma who progressed on sorafenib treatment (RESORCE): a randomised, double-blind, placebo-controlled, phase 3 trial. Lancet. 2017; 389: 56-66.

7. Puzzoni M, Silvestris N, Leone F, Giampieri R, Faloppi L, Demurtas L, Dell'Aquila E, Marino D, Brunetti O, Garattini SK, Ongaro E, Astara G, Orgiano L, et al. The Immune Revolution in Gastrointestinal Tumours: Leading the Way or Just Following? Target Oncology. 2016; 11: 593-603.

8. Prieto J, Melero I, Sangro B. Immunological landscape and immunotherapy for hepatocellular carcinoma. Nature Review Gastroenterology Hepatology. 2015; 12: 681-700.

9. Kassel R, Cruise MW, Iezzoni JC, Taylor NA, Pruett TL, Hahn YS. Chronically inflamed livers up-regulate expression of inhibitory B7 family members. Hepatology. 2009; 50: 1625-1637.

10. Okazaki T, Maeda A, Nishimura H, Kurosaki T, Honjo T. PD-1 immunoreceptor inhibits B cell receptor-mediated signaling by recruiting src homology 2-domain-containing tyrosine phosphatase 2 to phosphotyrosine. Proceding National Academy Science USA. 2001; 98: 13866-13871.

11. Knolle P, Schlaak J, Uhrig A, Kempf P, Meyer zum Büschenfelde KH, Gerken G. Human Kupffer cells secrete IL-10 in response to lipopolysaccharide (LPS) challenge. Journal Hepatology. 1995; 22: 226-229.

12. Bissell DM, Wang SS, Jarnagin WR, Roll FJ. Cellspecific expression of transforming growth factor-beta in rat liver. Evidence for autocrine regulation of hepatocyte proliferation. Journal Clinical Investigation. 1995; 96: 1447-1455.

13. Moorman JP, Wang JM, Zhang Y, XJ Ji, Ma CJ, Wu XY, Jia ZS, Wang KS, Yao ZQ. Tim-3 pathway controls regulatory and effector $\mathrm{T}$ cell balance during hepatitis $\mathrm{C}$ virus infection. Journal Immunolology. 2012; 189: 755-766.

14. Miamen AG, Dong H, Roberts LR. Immunotherapeutic approaches to hepatocellular carcinoma treatment. Liver Cancer. 2012; 1: 226-237.

15. Bertino G, Demma G, Ardiri A, Proiti M, Mangia A, Gruttadauria S, Toro A, Di Carlo I, Malaguarnera G, Bertino N, Malaguarnera M, Malaguarnera M. The immune system in hepatocellular carcinoma and potential new immunotherapeutic strategies. Biomedical Research International. 2015; 2015:12. doi: 10.1155/2015/731469.731469.

16. Li T, Yang Y, Hua X, Wang G, Liu W, Jia C, Tai Y, Zhang Q, Chen G. Hepatocellular carcinoma-associated fibroblasts trigger NK celldysfunction via PGE2 and IDO. Cancer Letter. 2012: 318: 154-161.

17. Unitt E, Marshall A, Gelson W, Rushbrook SM, Davies S, Vowler SL, Morris LS, Coleman N, Alexander GJ. Tumour lymphocytic infiltrate and recurrence of hepatocellular carcinoma following liver transplantation. Journal Hepatology. 2006; 45: 246-253.

18. Sakaguchi S, Setoguchi R, Yagi H, Nomura T. Naturally 
arising Foxp3-expressing CD25+CD4+ regulatory T cells in self-tolerance and autoimmune disease. Current Topics in Microbiology and Immunology. 2006; 305: 51-66.

19. Hori S, Nomura T, Sakaguchi S. Control of regulatory $T$ cell development by the transcription factor Foxp3. Science. 2003; 299:1057-61.

20. Vahedi G, Poholek A, Hand TW, Laurence A, Kanno Y, O'Shea JJ, Hirahara K. Helper T-cell identity and evolution of differential transcriptomes and epigenomes. Immunological Reviews. 2013; 252: 24-40.

21. Fu J, Xu D, Liu Z, Shi M, Zhao P, Fu B, Zhang Z, Yang H, Zhang H, Zhou C, Yao J, Jin L, Wang H, et al. Increased regulatory $\mathrm{T}$ cells correlate with $\mathrm{CD} 8 \mathrm{~T}$-cell impairment and poor survival in hepatocellular carcinoma patients. Gastroenterology. 2007; 132: 2328-2339.

22. Gao Q, Wang XY, Qiu SJ, Yamato I, Sho M, Nakajima Y, Zhou J, Li BZ, Shi YH, Xiao YS, Xu Y, Fan J. Overexpression of PD-L1 significantly associates with tumor aggressiveness and postoperative recurrence in human hepatocellular carcinoma. Clinical Cancer Research. 2009; 15:971-9.

23. Hato T, Zhu AX, Duda DG. Rationally combining antiVEGF therapy with checkpoint inhibitors in hepatocellular carcinoma. Immunotherapy. 2016; 8: 299-313.

24. Motz GT, Santoro SP, Wang LP, Garrabrant T, Lastra RR, Hagemann IS, La P, Feldman MD, Benencia F, Coukos G. Tumor endothelium FasL establishes a selective immune barrier promoting tolerance in tumors. Nature Medicine. 2014; 20: 607-615.

25. Voron T, Colussi O, Marcheteau E, Pernot S, Nizard M, Pointet AL, Latreche S, Bergaya S, Benhamouda N, Tanchot C, Stockmann C, Combe P, Berger A, et al. VEGF-A modulates expression of inhibitory checkpoints on CD8+ T cells in tumors. Journal of Experimental Medicine. 2015; 212: 139-48.

26. Arihara F, Mizukoshi E, Kitahara M, Takata Y, Arai $\mathrm{K}$, Yamashita T, Nakamoto Y, Kaneko S. Increase in CD14+HLA-DR-/low myeloid-derived suppressor cells in hepatocellular carcinoma patients and its impact on prognosis. Cancer Immunology, Immunotherapy. 2013; 62: 1421-30.

27. Grunewald M, Avraham I, Dor Y, Bachar-Lustig E, Itin A, Jung S, Chimenti S, Landsman L, Abramovitch R, Keshet E. VEGF-induced adult neovascularization: recruitment, retention, and role of accessory cells. Cell. 2006; 124: 17589.

28. Chen Y, Huang Y, Reiberger T, Duyverman AM, Huang P, Samuel R, Hiddingh L, Roberge S, Koppel C, Lauwers GY, Zhu AX, Jain RK, Duda DG. Differential effects of sorafenib on liver versus tumor fibrosis mediated by stromal derived factor $1 \mathrm{a} / \mathrm{C}-\mathrm{X}-\mathrm{C}$ receptor type 4 axis and myeloid differentiation antigen-positive myeloid cell infiltration in mice. Hepatology. 2014; 59: 1435-47.

29. Hipp MM, Hilf N, Walter S, Werth D, Brauer KM, Radsak
MP, Weinschenk T, Singh-Jasuja H, Brossart P. Sorafenib, but not sunitinib, affects function of dendritic cells and induction of primary immune responses. Blood. 2008; 111 : 5610-20.

30. Noman MZ, Desantis G, Janji B, Hasmim M, Karray S, Dessen P, Bronte V, Chouaib S. PD-L1 is a novel direct target of HIF-1 $\alpha$, and its blockade under hypoxia enhanced MDSC-mediated T cell activation. Journal of Experimental Medicine. 2014; 211: 781-90.

31. Chen Y, Ramjiawan RR, Reiberger T, Ng MR, Hato T, Huang Y, Ochiai H, Kitahara S, Unan EC, Reddy TP, Fan C, Huang P, Bardeesy N, et al. CXCR4 inhibition in tumor microenvironment facilitates anti-PD-1 immunotherapy in sorafenib-treated HCC in mice. Hepatology. 2015; 61: 1591-602.

32. Huang Y, Yuan J, Righi E, Kamoun WS, Ancukiewicz M, Nezivar J, Santosuosso M, Martin JD, Martin MR, Vianello F, Leblanc P, Munn LL, Huang P, et al. Vascular normalizing doses of antiangiogenic treatment reprogram the immunosuppressive tumor microenvironment and enhance immunotherapy. Proceedings of the National Academy of Sciences USA. 2012; 109: 17561-6.

33. Hong YP, Li ZD, Prasoon P, Zhang Q. Immunotherapy for hepatocellular carcinoma: From basic research to clinical use. World Journal Hepatology. 2015; 7: 980-992.

34. Jinushi M, Takehara T, Tatsumi T, Hiramatsu N, Sakamori R, Yamaguchi S, Hayashi N. Impairment of natural killer cell and dendritic cell functions by the soluble form of MHC class I-related chain A in advanced human hepatocellular carcinomas. Journal Hepatology. 2005; 43: 1013-1020.

35. Zerbini A, Pilli M, Laccabue D, Pelosi G, Molinari A, Negri E, Cerioni S, Fagnoni F, Soliani P, Ferrari C, Missale G. Radiofrequency thermalablation for hepatocellular carcinoma stimulates autologous NK-cell response. Gastroenterology, 2010; 138: 1931-1942.

36. NCT01147380: Safety Study of Liver Natural Killer Cell Therapy for Hepatoma Liver Transplantation (MIAMINK) (available at: https:/clinicaltrials.gov/ct2/show/study/ NCT01147380).

37. NCT02008929: to Evaluate the Efficacy and Safety of MG4101(Ex Vivo Expanded Allogeneic NK Cell) (MG4101) (available at: https://clinicaltrials.gov/ct2/show/ NCT02008929).

38. Jiang J, Wu C, Lu B. Cytokine-induced killer cells promote antitumor immunity. Journal Translational Medicine. 2013; 11: 83 .

39. Hui D, Qiang L, Jian W, Ti Z, Da-Lu K. A randomized, controlled trial of postoperative adjuvant cytokine-induced killer cells immunotherapy after radical resection of hepatocellular carcinoma. Digestive Liver Disease. 2009; 41: 36-41.

40. Pan K, Li YQ, Wang W, Xu L, Zhang YJ, Zheng HX, Zhao JJ, Qiu HJ, Weng DS, Li JJ, Wang QJ, Huang LX, He J, et al. The efficacy of cytokine-induced killer cell infusion 
as an adjuvant therapy for postoperative hepatocellular carcinoma patients. Annals Surgical Oncology. 2013; 20: 4305-4311.

41. Huang ZM, Li W, Li S, Gao F, Zhou QM, Wu FM, He N, Pan CC, Xia JC, Wu PH, Zhao M. Cytokine-induced killer cells in combination with transcatheter arterial chemoembolization and radiofrequency ablation for hepatocellular carcinoma patients. Journal Immunotherapy. 2013; 36: 287-293.

42. Lee JH, Lee JH, Lim YS, Yeon JE, Song TJ, Yu SJ, Gwak GY, Kim KM, Kim YJ, Lee JW, Yoon JH. Adjuvant immunotherapy with autologous cytokine-induced killer cells for hepatocellular carcinoma. Gastroenterology. 2015; 148: 1383-1391.

43. Ma Y, Xu YC, Tang L, Zhang Z, Wang J, Wang HX. Cytokineinduced killer (CIK) cell therapy for patients with hepatocellular carcinoma: efficacy and safety. Expert Hematology Oncology. 2012; 1: 11.

44. Zhu GQ, Shi KQ, Yu HJ, He SY, Braddock M, Zhou MT, Chen YP, Zheng MH. Optimal adjuvant therapy for resected hepatocellular carcinoma: a systematic review with network meta-analysis. Oncotarget. 2015; 6: 18151-61. doi: 10.18632/oncotarget.4098.

45. NCT01749865: CIK Treatment for HCC Patient Underwent Radical Resection (available at: https://clinicaltrials.gov/ ct2/show/NCT01749865).

46. NCT00769106: Study of Cytokine-induced Killer Cell (CIK) Treatment in Patients After Resection of Liver Cancer (HCC-CIK) (available at: https://clinicaltrials.gov/ ct2/show/NCT00769106).

47. Marra F, Tacke F. Roles for chemokines in liver disease. Gastroenterology. 2014; 147: 577.

48. Herzer K, Hofmann TG, Teufel A, Schimanski CC, Moehler M, Kanzler S, Schulze-Bergkamen H, Galle PR. IFN-alphainduced apoptosis in hepatocellular carcinoma involves promyelocytic leukemia protein and TRAIL independently of p53. Cancer Research. 2009; 69: 855-862.

49. Li P, Du Q, Cao Z, Guo Z, Evankovich J, Yan W, Chang Y, Shao L, Stolz DB, Tsung A, Geller DA. Interferon- $\gamma$ induces autophagy with growth inhibition and cell death in human hepatocellular carcinoma (HCC) cells through interferon-regulatory factor-1 (IRF-1). Cancer Letter. 2012; 314: 213-222.

50. Obora A, Shiratori Y, Okuno M, Adachi S, Takano Y, Matsushima-Nishiwaki R, Yasuda I, Yamada Y, Akita K, Sano T, Shimada J, Kojima S, Okano Y, et al. Synergistic induction of apoptosis by acyclic retinoid and interferonbeta in human hepatocellular carcinoma cells. Hepatology. 2002; 36: 1115-1124.

51. Li M, Lu C, Cheng J, Zhang J, Cao C, Xu J, Xu J, Pan $\mathrm{H}$, Zhong B, Tucker S, Wang D. Combination therapy with transarterial chemoembolization and interferon-alpha compared with transarterial chemoembolization alone for hepatitis B virus related unresectable hepatocellular carcinoma. Journal Gastroenterology Hepatology. 2009; 24: $1437-1444$.

52. Kasai KL, Ushio A, Kasai Y, Sawara K, Miyamoto Y, Oikawa K, Kuroda H, Takikawa Y, Suzuki K. Therapeutic efficacy of combination therapy with intra-arterial 5 -fluorouracil and systemic pegylated interferon $\alpha-2 b$ for advanced hepatocellular carcinoma with portal venous invasion. Cancer. 2012; 118: 3302-3310.

53. Jiang SL, Liu Y, Wang L, Duan C, Liu M. A metaanalysis and systematic review: adjuvant interferon therapy for patients with viral hepatitis-related hepatocellular carcinoma. World Journal Surgical Oncology. 2013; 24: 240 .

54. Wang LL, Jia D, Duan F, Sun Z, Liu X, Zhou L, Sun L, Ren S, Ruan Y, Gu J. Combined anti-tumor effects of IFN- $\alpha$ and sorafenib on hepatocellular carcinoma in vitro and in vivo. Biochemical Biophysical Research Community. 2012; 422: 687-692.

55. NCT01834963: P2 Study of Postoperative Interferon/ Fluorouracil vs Cisplatin/Fluorouracil for Hepatocellular Carcinoma (available at: https://clinicaltrials.gov/ct2/show/ NCT01834963).

56. Postow MA, Callahan MK, Wolchok JD. Immune checkpoint blockade in cancer therapy. Journal Clinical Oncology. 2015; 33: 1974-1982.

57. Harding JJ, Dika I El, Abou-Alfa GK. Immunotherapy in hepatocellular carcinoma: Primed to make a difference? Cancer. 2015; 122: 367-377.

58. Sangro B, Gomez-Martin C, de la Mata M, Iñarrairaegui M, Garralda E, Barrera P, Riezu-Boj JI, Larrea E, Alfaro C, Sarobe P, Lasarte JJ, Pérez-Gracia JL, et al. A clinical trial of CTLA-4 blockade with tremelimumab in patients with hepatocellular carcinoma and chronic hepatitis C. Journal Hepatology. 2013; 59: 81-88.

59. NCT01853618: Tremelimumab With Chemoembolization or Ablation for Liver Cancer. (available at: https:// clinicaltrials.gov/ct2/show/NCT01853618).

60. Duffy AG, Makarova-Rusher OV, Kerkar SP, Kleiner DE, Fioravanti S, Walker M, Carey S, Douglas Figg W, Steinberg SM, Anderson A, Abi-Jaoudeh N, Levi E, Wood BJ. et al. A pilot study of tremelimumab-a monoclonal antibody against CTLA 4-in combination with either trans catheter arterial chemoembolization (TACE) or radiofrequency ablation (RFA) in patients with hepatocellular carcinoma (HCC). Journal of Clinical Oncology. 2015: 33, S4081.

61. Melero I, Sangro B, Cheung Yau T, Hsu C, Kudo M, Crocenzi TS, Kim TY, Choo SP, Trojan J, Meyer T, Hobart Welling T, Yeo W, Chopra A, et al. Nivolumab dose escalation and expansion in patients with advanced hepatocellular carcinoma (HCC): The CheckMate 040 study. Journal of Clinical Oncology 35, 2017 (suppl 4S; abstract 226) .

62. Segal N, Hamid O, Hwu W. A phase I multi-arm dose- 
expansion study of the anti-programmed cell death-ligand-1 (PD-L1) antibody MEDI4736: preliminary data. Annals Oncology. 2014: iv361-iv372.

63. Zhu AX, Knox JJ, Kudo M, Chan SL, Finn RS, Siegel AB, Ma J, Watson P, Cheng AL. KEYNOTE-224: Phase II study of pembrolizumab in patients with previously treated advanced hepatocellular carcinoma. Journal of Clinical Oncology 35, 2017 (suppl 4S; abstract TPS504)

64. Finn RS, Chan SL, Zhu AX, Knox JJ, Cheng AL, Siegel AB, Bautista O, Watson P, Kudo M. KEYNOTE-240: Randomized phase III study of pembrolizumab versus best supportive care for second-line advanced hepatocellular carcinoma. Journal of Clinical Oncology 35, 2017 (suppl 4S; abstract TPS503).

65. Curran MA, Montalvo W, Yagita H, Allison JP. PD-1 and CTLA-4 combination blockade expands infiltrating T cells and reduces regulatory $\mathrm{T}$ and myeloid cells within $\mathrm{B} 16$ melanoma tumors. Proceedings of the National Academy of Sciences USA. 2010; 107: 4275-80.

66. NCT01658878: A Study to Evaluate the Effectiveness, Safety and Tolerability of Nivolumab and the Combination Nivolumab Plus Ipilimumab in Patients With Advanced Liver Cancer (CheckMate040) (available at: https:// clinicaltrials.gov/ct2/show/ NCT01658878).

67. Ma W, Gilligan BM, Yuan J, Li T. Current status and perspectives in translational biomarker research for PD-1/ PD-L1 immune checkpoint blockade therapy. Journal of Hematology and Oncolology 2016; 9: 47.

68. Ormandy LA, Farber A, Cantz T, Petrykowska S, Wedemeyer H, Horning M, Lehner F, Manns MP, Korangy F, Greten TF. Direct ex vivo analysis of dendritic cells in patients with hepatocellular carcinoma. World Journal Gastroenterology. 2006; 12: 3275-3282.

69. Cai XY, Gao Q, Qiu SJ, Ye SL, Wu ZQ, Fan J, Tang ZY. Dendritic cell infiltration and prognosis of human hepatocellular carcinoma. Journal Cancer Research Clinical Oncology. 2006. 132: 293-301.

70. Iwashita Y, Tahara K, Goto S, Sasaki A, Kai S, Seike M, Chen CL, Kawano K, Kitano S. A phase I study of autologous dendritic cell-based immunotherapy for patients with unresectable primary liver cancer. Cancer Immunology Immunotherapy. 2003; 50: 155-161.

71. Palmer DH, Midgley RS, Mirza N, Torr EE, Ahmed F, Steele JC, Steven NM, Kerr DJ, Young LS, Adams DH. A phase II study of adoptive immunotherapy using dendritic cells pulsed with tumor lysate in patients with hepatocellular carcinoma. Hepatology. 2009; 49: 124-132.

72. Mizukoshi E, Nakamoto Y, Arai K, Yamashita T, Mukaida N, Matsushima K, Matsui O, Kaneko S. Enhancement of tumorspecific $\mathrm{T}$-cell responses by transcatheter arterial embolization with dendritic cell infusion for hepatocellular carcinoma. International Journal Cancer. 2010; 126: 21642174

73. NCT01974661: Phase I Safety Study of Dendritic Cell
Vaccine to Treat Patients With Hepatocellular Carcinoma (available at: https://clinicaltrials.gov/ct2/show/ NCT01974661).

74. Butterfield LH, Ribas A, Meng WS, Dissette VB, Amarnani S, Vu HT, Seja E, Todd K, Glaspy JA, McBride WH, Economou JS. T-cell responses to HLA-A*0201 immunodominant peptides derived from alpha-fetoprotein in patients with hepatocellular cancer. Clinical Cancer Research. 2003; 9: 5902-5908.

75. Sawada Y, Yoshikawa T, Nobuoka D, Shirakawa H, Kuronuma T, Motomura Y, Mizuno S, Ishii H, Nakachi K, Konishi M, Nakagohri T, Takahashi S, Gotohda N, et al. Phase I trial of a glypican-3-derived peptide vaccine for advanced hepatocellular carcinoma: immunologic evidence and potential for improving overall survival. Clinical Cancer Research. 2012; 18: 3686-3696.

76. Nobuoka D, Yoshikawa T, Sawada Y, Fujiwara T, Nakatsura T. Peptide vaccines for hepatocellular carcinoma. Human Vaccines \& Immunotherapeutics. 2013; 9: 210-212.

77. Li SQ, Lin J, Qi CY, Fu SJ, Xiao WK, Peng BG, Liang LJ. GPC3 DNA vaccine elicits potent cellular antitumor immunity against HCC in mice. Hepatogastroenterology. 2014; 61: 278-284.

78. Butterfield LH, Economou JS, Gamblin TC, Geller DA. Alpha fetoprotein DNA prime and adenovirus boost immunization of two hepatocellular cancer patients. Journal Translational Medicine. 2014; 12: 86.

79. Greten TF, Forner A, Korangy F, N'Kontchou G, Barget N, Ayuso C, Ormandy LA, Manns MP, Beaugrand M, Bruix J. A phase II open label trial evaluating safety and efficacy of a telomerase peptide vaccination in patients with advanced hepatocellular carcinoma. BMC Cancer. 2010; 10: 209.

80. Kwilas AR, Donahue RN, Tsang KY, Hodge JW. Immune consequences of tyrosine kinase inhibitors that synergize with cancer immunotherapy. Cancer Cell Microenvironment. 2015; 2: 677.

81. NCT02562755: Hepatocellular Carcinoma Study Comparing Vaccinia Virus Based Immunotherapy Plus Sorafenib vs Sorafenib Alone (PHOCUS) (available at: https://clinicaltrials.gov/ct2/show/NCT02562755).

82. Safran H, Charpentier KP, Kaubisch A, Mantripragada K, Dubel G, Perez K, Faricy-Anderson K, Miner T, Eng Y, Victor J, Plette A, Espat J, Bakalarski P, et al. Lenalidomide for second-line treatment of advanced hepatocellular cancer: a Brown University oncology group phase II study. American Journal Clinical Oncology. 2015; 38: 1-4.

83. Ou DL, Chang CJ, Jeng YM, Lin YJ, Lin ZZ, Gandhi AK, Liao SC, Huang ZM, Hsu C, Cheng AL. Potential synergistic anti-tumor activity between lenalidomide and sorafenib in hepatocellular carcinoma. Journal Gastroenterology Hepatology. 2014; 29: 2021-2031.

84. Van Lint S, Heirman C, Thielemans K, Breckpot K. mRNA: From a chemical blueprint for protein production to an offthe-shelf therapeutic. Human Vaccine Immunotherapy. 
2013; 9: 265-274.

85. Van Lint S, Goyvaerts C, Maenhout S, Goethals L, Disy A, Benteyn D, Pen J, Bonehill A, Heirman C, Breckpot K, Thielemans K. Preclinical evaluation of TriMix and antigen mRNA-based antitumor therapy. Cancer Research. 2012; 72: 1661-1671.

86. Aerts M, Benteyn D, Van Vlierberghe H, Thielemans K, Reynaert H. Current status and perspectives of immunebased therapies for hepatocellular carcinoma. World Journal of Gastroenterology. 2016; 22: 253-61.

87. Gnoni A, Silvestri N, Licchetta A, Santini D, Scartozzi M, Ria R, Pisconti S, Petrelli F, Vacca A, Lorusso V. Metronomic chemotherapy from a rationale to clinical studies: a dream or reality? Critical Review Oncology Hematology. 2015; 95: 46-61.

88. Zitvogel L, Apetoh L, Ghiringhelli F, Kroemer G. Immunological aspects of cancer chemotherapy. Nature
Review Immunology. 2008; 8: 59-73.

89. Brandi G, de Rosa F, Agostini V, di Girolamo S, Andreone P, Bolondi L, Serra C, Sama C, Golfieri R, Gramenzi A, Cucchetti A, Pinna AD, Trevisani F, et al. Metronomic capecitabine in advanced hepatocellular carcinoma patients: a phase II study. Oncologist. 2013; 18: 1256-1257.

90. Heo J, Reid T, Ruo L, Breitbach CJ, Rose S, Bloomston M, Cho M, Lim HY, Chung HC, Kim CW, Burke J, Lencioni R, Hickman T, et al. Randomized dose-finding clinical trial of oncolytic immunotherapeutic vaccinia JX-594 in liver cancer. Nature Medicine. 2013; 19: 329-336.

91. Burke JM, Breitbach C, Patt RH. Phase IIb randomized trial of JX-594, a targeted multimechanistic oncolytic vaccinia virus, plus best supportive care (BSC) versus BS alone in patients with advanced hepatocellular carcinoma who have failed sorafenib treatment (TRAVERSE). Journal Clinical Oncology. 2012; 30, e14566. 